M. Masjkur

\title{
PERAN GURU PENDIDIKAN AGAMA ISLAM DALAM MEMBANGUN SELF CONTROL REMAJA DI SEKOLAH
}

\section{MASJKUR}

IAI Sunan Giri Bojonegoro

masjkur@sunan-giri.ac.id

\begin{abstract}
"Self control is the ability of the individual to inhibit or prevent an impulse from appearing in the form of behavior that violates or contradicts moral standards. In another definition self-control is a network that is intact or integrated between individuals and their environment. Individuals who have high self-control seek to find and apply appropriate ways to behave in varied situations. Self-control affects individuals to change their behavior according to social situations so as to manage the impression of being more responsive to situational, flexible, and warm and open guidelines. Self-control is concerned with how the individual controls his emotions and drives from within himself. According to the scientific concept, emotion control means directing emotional energy to a useful and socially acceptable expression channel. Teachers' efforts in establishing adolescent self-control means the efforts or endeavors undertaken by a teacher attain a goal in the process of building the ability of the individual adolescent to inhibit or prevent an impulse from appearing in the form of behavior that violates or contradicts moral standards. In building self-control teenagers in school, of course, a teacher must first have a good self-control and strong, so it can be used as a mirror for them. Based on the above description, there are two issues that will be discussed, namely: 1) How the role of Islamic Religious Education Teacher in building self-control teenagers in school, 2) What efforts can be done Islamic Teachers in building self-control teenagers in school. From the discussion can be concluded: 1)
\end{abstract}

19 AT-TUHFAH: Jurnal Keislaman. Vol. 7, No.1, 2018 
Islamic education teachers have a very important and strategic role in building selfcontrol teenagers in school. PAI Teachers have to act as mentors, advisors, models or models and evaluators in building self-control teenagers 2) The efforts made by PAI teachers in building self-control teenagers in schools, among others through the following activities: a) Educate by giving exemplary, b) Educate by implementing a policy of supervision and counseling together, c) Educate by doing habituation, d) Educate by fostering the discipline of learners."

Keywords : Islamic Education Teacher, Self Control

\section{PENDAHULUAN}

Istilah pubertas atau adolescensia sering dimaknai dengan masa remaja, yakni masa perkembangan sifat tergantung (dependence) terhadap orang tua ke arah kemandirian (independence), minat-minat seksual, perenungan diri, perhatian terhadap nilai-nilai estetika dan isu-isu moral. Harold Alberty mengatakan: "Remaja merupakan masa peralihan antara masa anak dan masa dewasa yakni berlangsung 11-13 tahun sampai 18-20 tahun menurut umur kalender kelahiran seseorang". ${ }^{1}$

Uraian di atas menunjukkan bahwa masa remaja adalah masa perkembangan. Salah satu tugas perkembangan yang harus dilakukan remaja adalah mempelajari apa yang diharapkan oleh kelompoknya lalu menyesuaikan tingkah lakunya dengan harapan sosial tanpa bimbingan, pengawasan, motivasi, dan ancaman sebagaimana sewaktu masih kecil (anak-anak). Dia juga dituntut mampu mengendalikan tingkah lakunya karena dia bukan lagi tanggung jawab orang tua atau guru.

Robert J. Havighurst mengatakan:

Tugas perkembangan itu merupakan suatu tugas yang muncul pada periode tertentu dalam rentang kehidupan individu, yang apabila tugas itu dapat berhasil dituntaskan akan membawa kebahagiaan dan kesuksesan dalam menuntaskan tugas berikutnya.

\footnotetext{
${ }^{1}$ Abin Syamsuddin Makmun, Psikologi Kependidikan, (Bandung: Remaja Rosdakarya, 2005), hlm. 94.
} 


\section{Masjkur}

Sementara jika gagal, maka akan menyebabkan ketidakbahagiaan pada diri individu yang bersangkutan, sehingga bisa menimbulkan penolakan masyarakat, kesulitankesulitan dalam menuntaskan tugas-tugas berikutnya. ${ }^{2}$

Berdasarkan penelitian empiris yang dilakukan Kohlberg pada tahun 1958, menyebutkan bahwa tahap-tahap perkembangan moral pada individu dibagi sebagai berikut:

\section{Tingkat Pra-konvensional}

Pada tingkat ini anak tanggap terhadap aturan-aturan budaya dan terhadap ungkapan-ungkapan budaya mengenai baik dan buruk, benar dan salah. Akan tetapi, hal ini semata-mata ditafsirkan dari segi sebab akibat fisik atau kenikmatan perbuatan (hukuman, keuntungan, pertukaran dan kemaikan).

\section{Tingkat Konvensional}

Pada tingkat ini anak hanya menurut harapan keluarga, kelompok atau bangsa. Ia memandang bahwa halo tersebut bernilai bagi dirinya sendiri, tanpa mengindahkan akibat yang segera dan nyata.

\section{Tingkat Pasca-konvensional}

Pada tingkat ini terdapat usaha yang jelas untuk merumuskan nilai-nilai dan prinsip moral yang memiliki keabsahan dan dapat diterapkan, terlepas dari otoritas kelompok atau orang yang berpegang pada prinsip-prinsip itu dan terlepas pula dari identifikasi individu sendiri dengan kelompok tersebut. ${ }^{3}$

Selanjutnya Kohlberg juga berpendapat bahwa:

Perkembangan moral ketiga, moralitas pasca-konvensional harus dicapai selama masa remaja. Sejumlah prinsip diterimanya melalui dua tahap. Pertama meyakini bahwa dalam keyakinan moral harus ada fleksibilitas sehingga memungkinkan dilakukan perbaikan dan perubahan standar moral bila menguntungkan semua anggota kelompok. Kedua menyesuaikan diri dengan standar sosial dan ideal untuk menjauhi hukuman

\footnotetext{
${ }^{2}$ Elfi Yuliana Rochmah, Psikologi Perkembangan, (Yogyakarta: Teras, 2005), hlm. 62.

${ }^{3}$ Enung Fatimah, Psikologi Perkembangan, Perkembangan Peserta Didik, (Bandung: Pustaka Setia, 2006), hlm. 122.
} 
sosial terhadap dirinya sendiri, sehingga perkembangan moralnya tidak lagi atas dasar keinginan pribadi, tetapi emenghormati orang lain. ${ }^{4}$

Akan tetapi pada kenyataannya banyak ditemukan remaja yang belum bisa mencapai tahap pasca-konvensional, dan juga pernah ditemukan remaja yang baru mencapai tahap pra-konvensional.

Fenomena tersebut banyak dijumpai pada remaja yang pada umumnya masih duduk di bangku SMA/SMK, seperti:

1. Berperangai tidak terpuji, meremehkan peraturan dan disiplin sekolah.

2. Suka berhura-hura dan bergerombol.

3. Mentaati peraturan sekolah hanya karena takut pada hukuman.

Dan tidak jarang kita mendengar perkelahian terjadi antar remaja yang tidak jelas sebabnya. Bahkan berkelahian dapat meningkat menjadi permusuhan kelompok, yang menimbulkan korban pada kedua belah pihak. Bila ditanyakan pada mereka, apa yang menyebabkan mereka berbuat kekerasan sesama remaja, dan apa masalahnya sehingga peristiwa yang memalukan tersebut terjadi, banyak yang menjawab bahwa mereka tidak sadar mengapa mereka secepat itu menjadi marah dan ikut berkelahi.

Fenomena di atas menggambarkan bahwa upaya remaja untuk mencapai moralitas dewasa; mengganti konsep moral khusus dengan konsep moral umum, merumuskan yang baru dikembangkan ke dalam kode moral sebagai pedoman tingkah laku, dan mengendalikan tingkah laku sendiri, merupakan upaya yang tidak mudah bagi remaja.

Agar remaja yang sedang mengalami perubahan cepat dalam tubuhnya itu mampu menyesuaikan diri dengan keadaan perubahan tersebut, maka berbagai usaha baik dari pihak orang tua, guru maupun orang dewasa lainnya sangat diperlukan.

Uzer Usman dalam bukunya Menjadi Guru Profesional menulis:

Salah satu peran guru adalah sebagai pembimbing dalam tugasnya sebagai pendidik. Guru harus membantu murid-muridnya agar mencapai kedewasaan secara optimal.

\footnotetext{
${ }^{4}$ Muhammad Al-Mighwar, Psikologi Remaja; Petunjuk bagi Guru dan Orang Tua, (Bandung: Pustaka Setia, 2006), hlm. 136.
} 


\section{Masjkur}

Artinya kedewasaan yang sempurna ( sesuai dengan kodrat yang dimiliki murid). Dalam peranan ini guru harus memperhatikan aspek-aspek pribadi setiap murid antara lain kematangan, kebutuhan, kemampuan, kecakapannya dan sebagainya agar mereka (murid) dapat mencapai tingkat perkembangan dan kedewasaan yang optimal. ${ }^{5}$

Prof. Dr. Zakiah Daradjat juga menulis:

Guru Agama yang bijaksana dan mengerti perkembangan perasaan remaja yang tidak menentu, dapat menggugahnya dengan petunjuk agama tentang pertumbuhan dan perkembangan seseorang yang sedang memasuki masa baligh (puber). Salah satu ketentuan, misalnya dengan memberikan pengertian tentang berbagai ibadah yang dulu telah dilakukan remaja, misalnya shalat, puasa dan sebagainya, sekarang diberikan hikmah dan makina psikologis bagi ibadahnya terswebut, misalnya makna shalat bagi keserhatan mentalnya. Ia dapat mkengungkapkan perasaan yang galau kepada Allah dan ia dapat berdoa memohon ampun atas kekeliruannya, ia boleh minta dan mengajukan berbagai harapan dan keinginan kepada Allah yang Maha Mengerti dan Maha Penyayang kepada hambaNya. ${ }^{6}$

Selanjutnya beliau juga mengatakan: "Dengan pemahaman baru tentang makna dan hikmah ajaran agama bagi kesehatan mental, dan kepentingan hidup pada uтитnya, remaja akan mampu mengatasi kesulitannya, dan mampu mengendalikan diri". 7

Menurut Konfusius yang ditulis Singgih D. Gunarsa mengatakan:

Self Control (kontrol diri) adalah kualitas diri (self-sufficiency) dan keteraturan diri (selfregulation). Sedangkan Self-Regulation adalah kemampuan individu untuk menahan dorongan-dorongan dan kemampuan individu untuk mengendalikan tingkah lakunya

\footnotetext{
${ }^{5}$ Uzer Usman, Menjadi Guru Profesional, (Bandung: Remaja Rosdakarya, 1995), hlm. 7.

${ }^{6}$ Zakiah Daradjat, Remaja Harapan dan Tantangan, (Jakarta: Bulan Bintang, 1995), hlm. 79.

${ }^{7}$ Zakiah Daradjat, Ilmu Jiwa Agama, (Jakarta: Bulan Bintang, 1990), hlm. 103.
}

23 AT-TUHFAH: Jurnal Keislaman. Vol. 7, No.1, 2018 
pada saat tidak adanya kontrol dari lingkungan. Sedangkan Self-Regulation yang baik merupakan kriteria dari Self-Control yang baik pula. ${ }^{8}$

Dengan kemampuan pengendalian diri (self control) yang baik, remaja diharapkan mampu mengendalikan dan menahan tingkah laku yang bersifat menyakiti dan merugikan orang lain atau mampu mengendalikan serta menahan tingkah laku yang bertentangan dengan norma-norma sosial yang berlaku. Remaja juga diharapkan dapat mengantisipasi akibat-akibat negatif yang ditimbulkan pada masa stroom and stress.

Berdasarkan uraian di atas, maka terdapat dua permasalahan yang akan dibahas, yaitu:

1. Bagaimana peran Guru Pendidikan Agama Islam dalam membangun self control remaja di sekolah.

2. Upaya apa saja yang dapat dilakukan Guru Agama Islam dalam membangun self control remaja di sekolah.

Berdasarakan permasalahan yang telah dikemukakan, maka penulisan ini bertujuan untuk mengetahui:

1. Mengetahui peran Guru Pendidikan Agama Islam dalam membangun self control remaja di sekolah

2. Mengetahui upaya apa saja yang dapat dilakukan Guru Agama Islam dalam membangun self control remaja di sekolah.

\section{GURU PENDIDIKAN AGAMA ISLAM}

\section{A. Pengertian Guru Pendidikan Agama Islam}

Untuk memudahkan suatu konsep yang dapat dijadikan suatu pengertian guru, maka perlu ditinjau dari beberapa pendapat para ahli pendidikan. Meskipun mereka berbeda pendapat, tetapi mempunyai maksud yang sama.

\footnotetext{
${ }^{8}$ Singgih. D. Gunarsa, Bunga Rampai Psikologi Perkembangan; Dari Anak sampai Usia Lanjut, (Jakarta: Gunung Mulia, 2006), hlm. 254.
}

AT-TUHFAH: Jurnal Keislaman. Vol. 7, No.1, 201824 
Guru adalah “orang yang pekerjaannya (mata pencahariannya, profesinya) mengajar". 9 Dalam masyarakat Jawa, guru dilacak melalui akronim gu dan ru. "Gu" diartikan dapat digugu (dianut) dan "ru" bisa diartikan ditiru (dijadikan teladan). ${ }^{10} \mathrm{Hal}$ senada juga diungkapkan oleh al-Ghazali sebagaimana dikutip oleh Zainuddin dkk. bahwa guru adalah "pendidik dalam artian umum yang bertugas serta bertanggung jawab atas pendidikan dan pengajaran".11 Jadi, guru adalah semua orang yang berusaha mempengaruhi, membiasakan, melatih, mengajar serta memberi suri tauladan dalam membentuk pribadi anak didik dalam bidang jasmani, rohani, intelektual dan ketrampilan yang akan dipertanggungjawabkan pada orang tua murid, masyarakat serta kepada Allah.

Sedangkan pengertian guru Pendidikan Agama Islam dalam Kapita Selekta Pendidikan Agama Islam adalah yang menggunakan rujukan hasil

Konferensi Internasional tentang pengertian guru Pendidikan Agama Islam adalah sebagai murabbi, muallim dan muaddib.

Pengertian murabbi adalah guru agama harus orang yang memiliki sifat rabbani, yaitu bijaksana, terpelajar dalam bidang pengetahuan tentang rabb. Pengertian muallim adalah seorang guru agama harus alimun (ilmuwan), yakni menguasai ilmu teoritik, memiliki kreativitas, komitmen yang sangat tinggi dalam mengembangkan ilmu serta sikap hidup yang selalu menjunjung tinggi nilai di dalam kehidupan sehari-hari. Sedangkan pengertian ta' dib adalah integrasi antara ilmu dan amal. ${ }^{12}$

Jadi, pengertian Guru Pendidikan Agama Islam adalah guru yang mengajar bidang studi Pendidikan Agama Islam yang mempunyai kemampuan sebagai pendidik serta bertanggung jawab terhadap peserta didik.

\section{B. Sifat-sifat Guru Pendidikan Agama Islam}

Menurut Abdurrahman an-Nahlawi, sifat-sifat guru adalah sebagai berikut:

\footnotetext{
${ }^{9}$ Departemen Pendidikan dan Kebudayaan, Kamus Besar Bahasa Indonesia, (Jakarta: Balai Pustaka, 1990), hlm. 288.

${ }^{10}$ Hadi Supeno, Potret Guru, (Jakarta: Pustaka Sinar Harapan, 1995), hlm 26.

${ }^{11}$ Zainuddin, dkk., Seluk Beluk Pendidikan al-Ghazali, (Jakarta: Bumi Aksara, 1991), hlm. 50.

${ }^{12}$ Chabib Thoha, Kapita Selekta Pendidikan Islam, (Yogyakarta: Pustaka Pelajar, 1996), hlm. 11-12.
} 
1. Guru hendaknya robbani dalam segala tujuan, tingkah laku dan pola pikirnya.

2. Guru hendaknya ikhlas dalam pekerjaannya.

3. Guru hendaknya mempunyai sifat sabar dalam mendidik.

Maksudnya, guru hendaknya dapat dijadikan sebagai contoh dalam amal dan perbuatannya.

Firman Allah dalam surat ash-Shaff ayat 2-3:

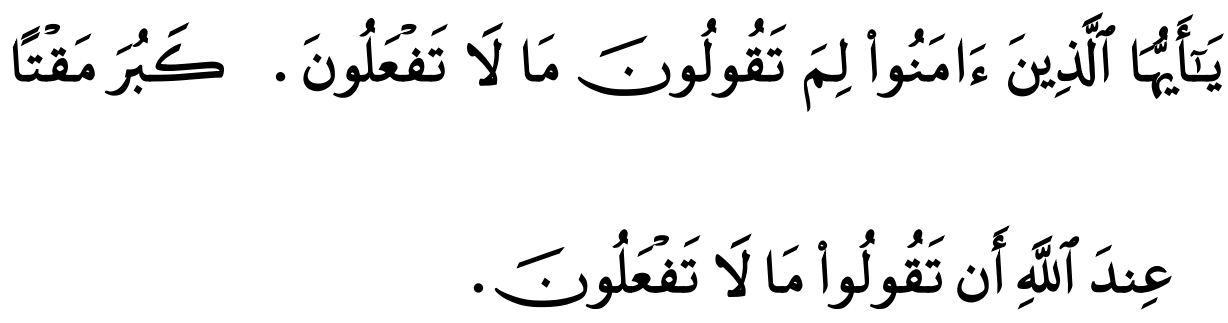

"Wahai orang-orang yang beriman, kenapakah kamu mengatakan sesuatu yang tidak kamu kerjakan? Amat besar kebencian di sisi Allah bahwa kamu mengatakan apa-apa yang tidak kamu kerjakan". ${ }^{13}$

4. Guru hendaknya bersifat jujur dalam menyampaikan apa yang diserukan kepada anak didik.

5. Guru hendaknya selalu membekali diri dengan berbagai macam ilmu dan terus menerus mengadakan pengkajian.

6. Guru hendaknya menguasai berbagai macam metode pelajaran dan menggunakannya dengan tepat.

7. Guru hendaknya mampu mengadakan pengelolaan terhadap siswa serta tegas dan dapat berlaku adil.

8. Guru hendaknya memahami jiwa anak, sehingga dapat memperlakukan siswanya sesuai dengan kemampuannya.

\section{Peranan Guru dalam Pembelajaran}

Guru memiliki andil yang sangat besar terhadap keberhasilan pembelajaran di sekolah. Guru sangat berperan dalam membantu perkembangan peserta didik untuk

\footnotetext{
${ }^{13}$ Departemen Agama RI, Al-Qur'an dan Terjemahnya, (Surabaya: Mekar, 2004), hlm. 805.
} 


\section{Masjkur}

mewujudkan hidupnya secara optimal. Adapun peranan guru dalam pembelajaran adalah sebagai berikut :

\section{Guru Sebagai Educator (Pendidik)}

Sebagai seorang pendidik guru harus memiliki cakupan ilmu yang cukup luas. Guru merupakan pendidik yang menjadi tokoh, panutan dan identifikasi bagi para peserta didik, dan lingkungannya. Oleh karena itu, guru harus memiliki standar kualitas tertentu, yang mencakup tanggung jawab, wibawa, mandiri dan disiplin. Dalam kaitanya dengan rasa tanggung jawab seorang guru harus mengetahui serta memahami nilai, norma moral, dan social, serta berusaha berperilaku dan berbuat sesuai dengan nilai dan norma tersebut. Guru juga harus bertanggung jawab terhadap segala tindakannya dalam pembelajaran di sekolah, dan dalam kehidupan bermasyarakat. ${ }^{14}$

\section{Guru Sebagai Pengajar}

Kegiatan belajar peserta didik dipengaruhi oleh berbagai faktor, seperti motivasi, kematangan, hubungan peserta didik dengan guru, kemampuan verbal, tingkat kebebasan, rasa aman dan keterampilan guru dalam berkomunikasi. Jika faktor-faktor di atas dipenuhi, maka melalui pembelajaran peserta didik dapat belajar dengan baik. Guru harus berusaha membuat sesuatu menjadi jelas bagi peserta didik dan terampil dalam memecahkan masalah. ${ }^{15}$

\section{Guru Sebagai Pembimbing}

Guru dapat diibaratkan sebagai pembimbing perjalanan, yang berdasarkan pengetahuan dan pengalamannya bertanggungjawab atas kelancaran perjalanan itu. Dalam hal ini, istilah perjalanan tidak hanya menyangkut fisik tetapi juga perjalanan mental, emosional, kreatifitas, moral dan spiritual yang lebih dalam dan kompleks. ${ }^{16}$

\footnotetext{
${ }^{14}$ E.Mulyasa, Manajemen Berbasis Sekolah. Strategi dan Implementasi (Bandung: Remaja Rosdakarya, 2011), hlm. 37

${ }^{15}$ E. Mulyana, Manajemen ........, hlm. 38

${ }^{16}$ E. Mulyana, Manajemen ........, hlm. 41.
} 


\section{Guru Sebagai Penasehat}

Guru merupakan seorang penasehat bagi peserta didik, bahkan juga bagi orang tua, meskipun mereka tidak memiliki latihan khusus sebagai penasehat dan dalam beberapa hal tidak dapat berharap untuk menasehati orang. Peserta didik senantiasa berhadapan dengan kebutuhan untuk membuat keputusan dan dalam prosesnya akan lari kepada gurunya. Agar guru dapat menyadari perannya sebagai orang kepercayaan dan penasihat secara lebih mendalam, ia harus memahami psikologi kepribadian dan ilmu kesehatan mental. ${ }^{17}$

\section{SELF CONTROL (KONTROL DIRI)}

\section{A. Pengertian Self Control}

Self control merupakan tingkah laku mengendalikan diri atau memonitor gagasan-gagasan atau ide dalam dirinya dengan berbagai cara, baik pada saat tidak ada tekanan maupun saat terjadi pertentangan dengan tekanan-tekanan yang ada dalam situasi yang dihadapinya. ${ }^{18}$

Definisi lain yang dikemukakan oleh Berk menyebutkan bahwa, "Self control merupakan kemampuan individu untuk menghambat atau mencegah suatu impuls agar tidak muncul dalam bentuk tingkah laku yang melanggar atau bertentangan dengan standar moral".

Kontrol diri didefinisikan Roberts sebagai suatu jalinan yang secara utuh atau terintegrasi antara individu dengan lingkungannya. Individu yang memiliki kontrol diri tinggi berusaha menemukan dan menerapkan cara yang tepat untuk berperilaku dalam situasi yang bervariasi. Kontrol diri mempengaruhi individu untuk mengubah perilakunya sesuai dengan situasi sosial sehingga dapat mengatur kesan lebih responsif terhadap petunjuk situasional, fleksibel, dan bersikap hangat serta terbuka. ${ }^{19}$

Kontrol diri berkaitan dengan bagaimana individu mengendalikan emosi serta dorongan-dorongan dari dalam dirinya. Menurut konsep ilmiah, pengendalian emosi

\footnotetext{
${ }^{17}$ E. Mulyana, Manajemen ........, hlm. 43.

${ }^{18}$ Liebert, R. M, Development Pshycology, (New Delhi: Prentice Hall of India, 1979), hlm. 342.

19 M. Nur Ghufron dan Rini Risnawita S., Teori-Teori Psikologi, ( Yogyakarta: Ar-Ruzz Media, 2014), hlm. 22-13
} 


\section{Masjkur}

berarti mengarahkan energy emosi ke saluran ekspresi yang bermanfaat dan dapat diterima secara sosial. Konsep ilmiah menitik beratkan pada pengendalian. ${ }^{20}$

\section{B. Jenis-jenis Self Control}

Menurut Block and Block ada tiga jenis kontrol yaitu:

1. Over control, yaitu kontrol yang berlebihan dan menyebabkan seseorang banyak mengontrol dan menahan diri untuk bereaksi terhadap suatu stimulus.

2. Under control, yaitu kecenderungan untuk melepaskan implus yang bebas tanpa perhitungan yang masak.

3. Approprite control, yaitu control yang memungkinkan individu mengendalikan implusnya secara tepat. ${ }^{21}$

\section{Aspek-aspek dalam Self Control}

Berdasarkan konsep Averill terdapat tiga aspek dalam kemampuan mengontrol diri, yaitu: $^{22}$

\section{Behavior Control (Mengontrol perilaku).}

Merupakan suatu tindakan langsung terhadap lingkungan. Aspek ini terdiri dari 2 komponen, yaitu: mengatur pelaksanaan (regulated administration), dan memodifikasi stimulus (stimulus modifiability). Kemampuan mengatur pelaksaan merupakan kemampuan individu untuk menentukan siapa yang akan mengendalikan situasi atau keadaan dirinya sendiri atau sesuatu diluar dirinya. Individu yang mempunyai kemampuan mengontrol diri dengan baik akan mampu perilakunya sendiri, dan jika individu tersebut tidak mampu, maka akan menggunakan sumber eksternal dari luar dirinya. Kemampuan mengatur stimulus adalah kemampuan untuk mengetahui bagaimana dan kapan suatu stimulus yang tidak dikehendaki dating.

\section{Cognitive Control (Mengontrol Kognisi).}

20 M. Nur Ghufron dan Rini Risnawita S., Teori-Teori Psikologi ........, hlm. 23

${ }^{21}$ M. Nur Ghufron dan Rini Risnawita S., Teori-Teori Psikologi ........, hlm. 27

${ }^{22}$ M. Nur Ghufron dan Rini Risnawita S., Teori-Teori Psikologi ........, hlm. 29-31 
Merupakan kemampuan individu untuk mengolah informasi yang tidak diinginkan dengan cara menginterpretasikan, menilai, atau menggabungkan suatu kejadian dalam suatu kerangka kognitif sebagai adaptasi psikologi untuk mengurangi tekanan. Aspek ini terdiri dari 2 komponen, yaitu: memperoleh informasi ( information gain) dan melakukan penilaian (apparsial). Informasi yang dimiliki individu atas suatu kejadian yang tidak menyenangkan dapat diantisipasi dengan berbagai pertimbangan, serta individu akan melakukan penilaian dan berusaha untuk menafsirkannya melalui segi-segi positif secara subjektif.

\section{Decisional Control (Mengontrol Keputusan).}

Kemampuan untuk memilih hasil yang diyakini individu, dalam menentukan pilihan akan berfungsi baik dengan adanya suatu kesempatan, kebebasan, atau kemungkinan pada diri individu untuk memilih kemungkinan tindakan. Aspek ini terdiri dari 2 komponen juga, yaitu: mengantisipasi peristiwa dan menafsirkan peristiwa, dimana individu dapat menahan dirinya.

Kemampuan mengontrol diri tergantung dari ketiga aspek di atas, kontrol diri ditentukan oleh seberapa jauh aspek itu mendominasi atau terdapat kombinasi dari beberapa aspek dalam mengontrol diri.

\section{Faktor-faktor yang mempengaruhi Self Control}

Sebagaimana faktor psikologis kontrol diri dipengaruhi beberapa faktor diantaranya adalah:

1. Faktor internal, yang mempengaruhi kontrol diri seseorang adalah faktor usia dan kematangan, semakin bertambah usia, semakin baik kemampuan mengontrol diri seseorang itu. 
M. Masjkur

2. Faktor eksternal, meliputi keluarga, dalam lingkungan keluarga terutama orang tua akan menentukan bagaimana kemampuan mengontrol diri seseorang. ${ }^{23}$

\section{E. Prinsip-prinsip dalam Self Control}

Prinsi-prinsip dalam membangun self control meliputi:

1. Prinsip kemoralan

Setiap agama pasti mengajarkan moral yang baik bagi setiap pemeluknya, misalnya tidak mencuri, tidak membunuh, tidak menipu, tidak berbohong, tidak mabuk-mabukan, tidak melakukan tindakan asusila maupun tidak merugikan orang lain. Saat ada dorongan hati untuk melakukan sesuatu yang negatif, maka kita dapat bersegera lari ke rambu-rambu kemoralan. Apakah yang kita lakukan ini sejalan atau bertentangan dengan nilai-nilai moral dan agama. Saat terjadi konflik diri antara ya atau tidak, mau melakukan atau tidak, kita dapat mengacu pada prinsip moral di atas.

2. Prinsip kesadaran

Prinsip ini mengajarkan kepada kita agar senantiasa sadar saat suatu bentuk pikiran atau perasaan yang negatif muncul. Pada umumnya orang tidak mampu menangkap pikiran atau perasaan yang muncul, sehingga mereka banyak dikuasai oleh pikiran dan perasaan mereka. Misalnya seseorang menghina atau menyinggung kita, maka kita marah. Nah, kalau kita tidak sadar atau waspada maka saat emosi marah ini muncul, dengan begitu cepat, tiba-tiba kita sudah dikuasai kemarahan ini. Jika kesadaran diri kita bagus maka kita akan tahu saat emosi marah ini muncul, menguasai diri kita dan kemungkinan akan melakukan tindakan yang akan merugikan diri kita dan orang lain. Saat kita berhasil mengamati emosi maka kita dapat langsung menghentikan pengaruhnya. Jika masih belum bisa atau dirasa berat sekali untuk mengendalikan diri, maka kita dapat melarikan pikiran kita pada prinsip moral.

\footnotetext{
${ }^{23}$ M. Nur Ghufron dan Rini Risnawita S., Teori-Teori Psikologi ........, hlm. 32.
} 


\section{Prinsip perenungan}

Ketika kita sudah benar-benar tidak tahan untuk meledakkan emosi karena amarah dan perasaan tertekan, maka kita bisa melakukan sebuah perenungan. Kita bisa menanyakan pada diri sendiri tentang berbagai hal, misalnya apa untungnya saya marah, apakah benar reaksi saya seperti ini, mengapa saya marah atau apakah alasan saya marah ini sudah benar. Dengan melakukan perenungan, maka kita akan cenderung mampu mengendalikan diri. Secara sederhana dapat digambarkan bahwa saat emosi aktif maka logika kita tidak jalan, sehingga saat kita melakukan perenungan atau berpikir secara mendalam maka kadar kekuatan emosi atau keinginan kita akan cenderung menurun.

4. Prinsip kesabaran

Pada dasarnya emosi kita naik - turun dan timbul, tenggelam. Emosi yang bergejolak merupakan situasi yang sementara saja, sehingga kita perlu menyadarinya bahwa kondisi ini akan segera berlalu seiring bergulirnya waktu. Namun hal ini tidaklah mudah karena perlu adanya kesadaran akan kondisi emosi yang kita miliki saat itu dan tidak terlalu larut dalam emosi. Salah satu cara yang perlu kita gunakan adalah kesabaran, menunggu sampai emosi negatif tersebut surut kemudian baru berpikir untuk menentukan respon yang bijaksana dan bertanggung jawab (reaksi yang tepat).

\section{Prinsip pengalihan perhatian}

Situasi dan kondisi yang memberikan tekanan psikologis sering menghabiskan waktu, tenaga dan pikiran yang cukup banyak bagi seseorang untuk menghadapinya. Apabila berbagai cara (4 prinsip sebelumnya) sudah dilakukan untuk berusaha menghadapi namun masih sulit untuk mengendalikan diri, maka kita bisa menggunakan prinsip ini dengan menyibukkan diri dengan pikiran dan aktifitas yang positif. Ketika diri kita disibukkan dengan pikiran positif yang lain, maka situasi yang menekan tersebut akan terabaikan. Begitu pula manakala kita menyibukkan diri dengan aktifitas lain yang positif, maka emosi yang ingin meledak akibat peristiwa yang tidak kita sukai tersebut akan menurun bahkan 


\section{Masjkur}

hilang. Saat kita berhasil memaksa diri memikirkan hanya hal-hal yang positif maka emosi kita akan ikut berubah kearah yang positif juga.

\section{UPAYA YANG DILAKUKAN GURU AGAMA DALAM MEMBANGUN SELF CONTROL}

Upaya dalam kamus besar bahasa Indonesia berarti usaha, akal, ikhtiar untuk mencapai suatu maksud, memecahkan persoalan dan mencari jalan keluar. Sedangkan upaya guru dalam membangun self control remaja berarti usaha atau ikhtiar yang dilakukan oleh seorang guru mencapai suatu tujuan dalam proses membangun kemampuan individu remaja untuk menghambat atau mencegah suatu impuls agar tidak muncul dalam bentuk tingkah laku yang melanggar atau bertentangan dengan standar moral. Dalam membangun self control remaja di sekolah, tentunya seorang guru terlebih dahulu harus memiliki self control yang baik dan kuat, sehingga dapat dijadikan cermin bagi mereka.

Adapun upaya-upaya yang dapat dilakukan guru dalam membangun self control peserta didik antara lain sebagai berikut :

1. Mendidik dengan metode keteladanan

Keteladanan hendaknya diartikan dalam arti luas, yaitu berbagai ucapan, sikap dan perilaku yang melekat pada diri pendidik. Berbagai macam contoh keteladanan telah dilakukan oleh Nabi Muhamad SAW dengan sangat berhasil, karena Muhamad adalah guru manusia, guru bangsa dan guru umat, bahkan dapat dikatakan sebagai guru multidimensi yang tiada taranya.

2. Mendidik dengan Pembiasaan

Pendidikan merupakan usaha sadar manusia dalam mencapai tujuan, yang dalam prosesnya diperlukan metode yang efektif dan menyenangkan. Untuk itu dalam mewujudkan self control yang baik diperlukan pembiasaan yang mengarah pada pembangunan self control peserta didik.

Pembiasaan adalah sesuatu yang sengaja dilakukan secara berulang-ulang

agar sesuatu itu dapat menjadi kebiasaan. Pembiasaan sebenarnya berintikan pengalaman, yang dibiasakan itu adalah sesuatu yang diamalkan. Diantara 
pembiasaan yang dilakukan di sekolah adalah disiplin dan mematuhi peraturan sekolah, terbiasa senyum ramah pada orang, dan kebiasaan- kebiasaan lain yang menjadi aktivitas sehari-hari. Untuk bisa melakukannya memang menuntut orang tua dan guru bisa menjadi teladan pertama dan utama bagi anak.

3. Mendidik denganmenerapkan kebijakan pengawasan dan pendampingan bersama.

Dalam dunia pendidikan tidak bisa terlepas dari kerjasama dan koordinasi yang intensif antara guru dan semua unsur yang terkait. Hal tersebut demi terwujudnya peserta didik yang mempunyai kemampuan kognitif, afektif dan psikomotorik sesuai harapan bersama. Pengawasan dan pendampingan sangat diperlukan dalam proses membangun self control peserta didik. Pengawasan yang dilakukan di sini adalah dengan cara mengawasi semua kegiatan, tingkah laku, dan bicara peserta didik dalam kegiatan proses pembelajaran baik di dalam kelas maupun di luar kelas.

4. Mendidik dengan pembinaan disiplin peserta didik

Dalam rangka mensukseskan pembangunan self control (kontrol diri), guru harus mampu menumbuhkan disiplin peserta didik, terutama disiplin diri. Sebagai seorang guru harus mampu membantu peserta didik mengembangkan pola perilakunya, meningkatkan standart perilakunya dan melaksanakan aturan sebagai alat untuk menegakan kedisiplinan. Untuk mendisiplinkan peserta didik perlu dimulai dengan prinsip yang sesuai dengan tujuan pendidikan sekolah, yakni sikap taat pada aturan dan kebijakan sekolah, sehingga peraturan disiplin perlu berpedoman pada peraturan sekolah tersebut. Dalam hal ini guru berfungsi sebagai pengemban ketertiban, yang patut digugu dan ditiru, tetapi tidak diharapkan sikap otoriter. Membina disiplin peserta didik harus mempertimbangkan berbagai situasi, dan memahami faktor-faktor yang mempengaruhinya.

\section{KESIMPULAN}

Dari pembahasan di atas dapat disimpulkan: 
M. Masjkur

1. Guru pendidikan agama Islam mempunyai peranan yang sangat penting dan strategis dalam membangun self control remaja di sekolah. Guru PAI harus berperan sebagai pembimbing, penasehat, model atau teladan dan evaluator dalam membangun self control remaja.

2. Adapun upaya yang dilakukan guru PAI dalam membangun self control remaja di sekolah antara lain melalui kegiatan berikut :
a. Mendidik dengan memberikan keteladanan.
b. Mendidik dengan menerapkan kebijakan pengawasan dan pendampingan bersama.
c. Mendidik dengan melakukan pembiasaan.
d. Mendidik dengan pembinaan kedisiplinan peserta didik.

\section{Daftar Pustaka}

Al-Mighwar, Muhammad, 2006, Psikologi Remaja; Petunjuk bagi Guru dan Orang Tua, Bandung: Pustaka Setia.

Daradjat, Zakiah, 1990, Ilmu Jiwa Agama, Jakarta: Bulan Bintang.

-----------------, 1995, Remaja Harapan dan Tantangan, Jakarta: Bulan Bintang.

Departemen Agama RI, Al-Qur'an dan Terjemahnya, Surabaya: Mekar, 2004.

Departemen Pendidikan dan Kebudayaan, Kamus Besar Bahasa Indonesia, Jakarta: Balai Pustaka, 1990.

Fatimah, Enung, 2006, Psikologi Perkembangan, Perkembangan Peserta Didik, Bandung: Pustaka Setia.

35 AT-TUHFAH: Jurnal Keislaman. Vol. 7, No.1, 2018 
Ghufron, M. Nur, dan Rini Risnawita S., 2014, Teori-Teori Psikologi, Yogyakarta: ArRuzz Media.

Gunarsa, Singgih D., 2006, Bunga Rampai Psikologi Perkembangan; Dari Anak sampai Usia Lanjut, Jakarta: Gunung Mulia.

M., Liebert, R., 1979, Development Pshycology, New Delhi: Prentice Hall of India.

Makmun, Abin Syamsuddin, 2005, Psikologi Kependidikan, Bandung: Remaja Rosdakarya

Mulyasa, E., 2011, Manajemen Berbasis Sekolah. Strategi dan Implementasi Bandung: Remaja Rosdakarya.

Rochmah, Elfi Yuliana, 2005, Psikologi Perkembangan, Yogyakarta: Teras.

Supeno, Hadi, 1995, Potret Guru, Jakarta: Pustaka Sinar Harapan.

Thoha, Chabib, 1996, Kapita Selekta Pendidikan Islam, Yogyakarta: Pustaka Pelajar.

Usman, Uzer, 1995, Menjadi Guru Profesional, Bandung: Remaja Rosdakarya.

Zainuddin, dkk., Seluk Beluk Pendidikan al-Ghazali, Jakarta: Bumi Aksara, 1991. 